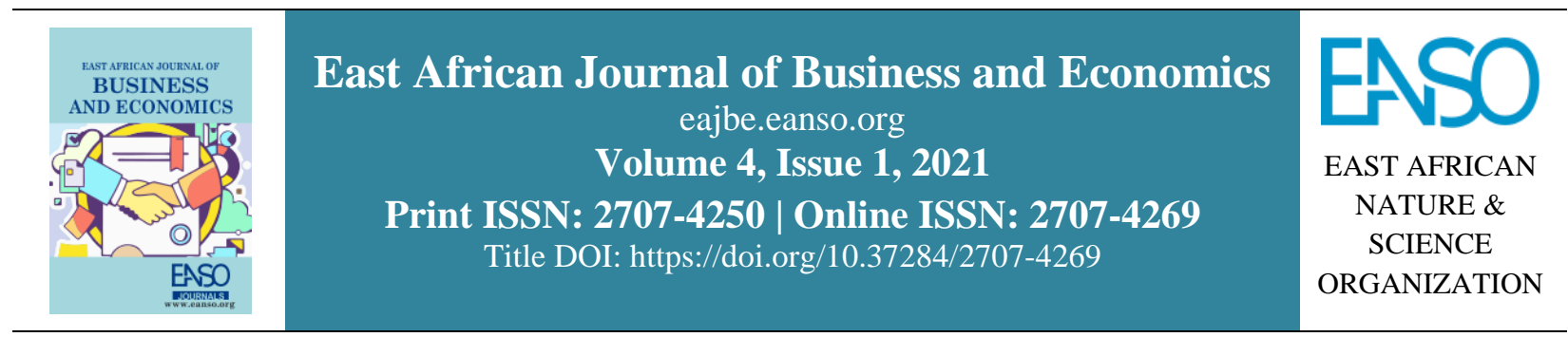

Original Article

\title{
Stakeholder Consultation and Implementation Water Projects: A Case of Machakos County, Kenya.
}

\author{
Nicholas K. Kosgei ${ }^{1 *}$ \\ ${ }^{1}$ The Catholic University of Eastern Africa, P.O BOX 62157-00200. Nairobi, Kenya \\ *Correspondence ORCID ID: https://orcid.org/0000-0002-9164-6637; email: kibetkosgei99@ gmail.com.
}

Article DOI: https://doi.org/10.37284/eajbe.4.1.472

\section{Date Published: ABSTRACT}

12 November 2021 For projects to be successfully implemented, consultation between the implementing agencies should be factored in as a project planning and

Keywords: management process. This paper looks at the influence of stakeholder Consultation, consultation on the implementation of water projects in Machakos Stakeholder, County, Kenya. The study targeted 172 water projects under

Implementation,

Water,
County.

Water,
County. implementation in the County of Machakos with respondents being seven members of project management committees. A simple random sampling technique was used in selecting 17 water projects. A questionnaire was used to collect data from 120 respondents managing 17 water projects. Quantitative collected data was analysed using descriptive (means, standard deviation, frequencies, and percentages) inferential statistics (correlation statistics). The study established a strong positive correlation ( $r=0.652)$ between the strategy of consulting stakeholders and the implementation of water projects. The study concluded that increased stakeholders' consultation would result in effective water projects implementation in the county. The study recommends that there is a need for the identification of link persons or officials who will always represent them during the implementation process.

\section{APA CITATION}

Kosgei, N. K. (2021). Stakeholder Consultation and Implementation Water Projects: A Case of Machakos County, Kenya. East African Journal of Business and Economics, 4(1), 14-21. https://doi.org/10.37284/eajbe.4.1.472

\section{CHICAGO CITATION}

Kosgei, Nicholas K. 2021. "Stakeholder Consultation and Implementation Water Projects: A Case of Machakos County, Kenya.”. East African Journal of Business and Economics 4 (1), 14-21. https://doi.org/10.37284/eajbe.4.1.472

14 | This work is licensed under a Creative Commons Attribution 4.0 International License. 


\section{HARVARD CITATION}

Kosgei, N. K. (2021) "Stakeholder Consultation and Implementation Water Projects: A Case of Machakos County, Kenya", East African Journal of Business and Economics, 4 (1), pp. 14-21. doi: 10.37284/eajbe.4.1.472.

\section{IEEE CITATION}

N. K. Kosgei, "Stakeholder Consultation and Implementation Water Projects: A Case of Machakos County, Kenya", EAJBE, vol. 4, no. 1, pp. 14-21, Nov. 2021.

\section{MLA CITATION}

Kosgei, Nicholas K. "Stakeholder Consultation and Implementation Water Projects: A Case of Machakos County, Kenya". East African Journal of Business and Economics, Vol. 4, no. 1, Nov. 2021, pp. 14-21, doi:10.37284/eajbe.4.1.472

\section{INTRODUCTION}

Measuring project implementation level is a critical factor in optimising the performance of projects (Project Management Institute-PMI, 2013). Measuring project implementation is significant since it gives a clear idea of the project's progress. Projects are designed and implemented to better the standards of people living in that particular place (Shah, \& Haider, 2014; Teye et al., 2016; Chinyavu, 2016). However, poor project implementation is seen as a genesis of mistrust from both private and public sector customers (Waghmare et al., 2016). The failure of any project is associated with drawbacks occurring during the execution stage (Mortensen, 2016). This makes the implementation of projects a prominent issue in project delivery all over the world. This is so because projects involve defined objectives, which must be achieved, and more materials that require effective use (Pellinen, 2016). There are various parameters for the implementation of projects. Adan (2012) states that the implementation and performance of a project are complex and could consist of: delivery speeds, construction speed, customer satisfaction level, and unit costs.

According to Project Management Institute (2013), projects goals and objectives cannot be realised without the effective engagement of all stakeholders concerned. The increased welfare of the residents in water projects calls for a close assessment of project performance from a social perspective (Fikkert, 2015). Stakeholder engagement covers various efforts to understand and involve stakeholders in a given organisation's activities and decisions (Kaur, 2014). In projects, stakeholders can be engaged in consultation, information disclosure, collaboration, and involvement. At first, the purpose of consultation as an engagement strategy is to reach a consensus (Mannya, 2012). Consultation with

15 This work is licensed under a Creative Commons Attribution 4.0 International License. stakeholder(s) refers to a two-way process of communiqué among the project company and its partners and involves commencing and maintaining positive association within a period of time (IFC, 2007). The process of Stakeholder consultation consists of identifying the inputs given by the stakeholders considered relevant in the project to be completed in determining the risk-benefit relationship and the weight given to each priority (Malachira, 2017). Different projects have various degrees of consulting stakeholders. For example, projects that will have potential social and environmental impacts, the consultation process is not limited to one discussion but sequences of discussions to help develop a logic of understanding amongst the various stakeholders with regard to development and the hazards, dangers, and threats linked with it, impacts, opportunities and mitigation measures (International Finance, 2007). At first, the consultation could be by way of stakeholders through advocacy and lobbying, exchanging views and information (Bashir, 2010). Secondly, stakeholders deliberate openly through public debate and presentations of issues of various community contexts (Atiibo, 2012). It entails crossfertilisation of ideas and views between and among equal stakeholders to reach collective decisions (Malachira, 2017). The consultation also entails informal meetings and discussions among stakeholders with the view of reaching a majority decision or consensus on issues of common interest while considering the perceptions of the minority and special groups (Ndirangu, 2021). Constructing and implementing successful dialogues persuade stakeholders and organisations to consult more despite challenges, but fruitful, the responsibility of paying attention to and studying from one another to improve performance (Kaur, 2014). The study aims to determine the effect of stakeholder consultation on water projects implementation by 
the county government of Machakos, Kenya. The study hypothesised that:

Ha: There is a significant effect of stakeholder consultation on water projects implementation by the county government of Machakos, Kenya

\section{LITERATURE REVIEW}

Research studies have been done in relation to consultation and implementation of projects. In Hong Kong and Australia, Rowlinson and Cheung (2018) looked at stakeholder management issues through a study design that did recognise contextual variables of projects that, through perpetual procedures, affect empowerment and so project results in an outcome. The research was exploratory in nature and the goal was to expose those characteristics, which permitted management of relationships to improve the performance of the project. A triangulated approach, using quantitative and qualitative methods, was adopted. The conversation was renowned for being an important engine in trust development procedures. Participants generally indicated that honest conversation among project team members was one significant variable in accelerating efficient management of the relationship. One usual illustration in the Australia road construction project was the implementer being enthusiastic to openly communicate and say issues concerning risk or problems that were anticipated. Unofficial channels of communication like faxing, emails, face-to-face conversations, and telephone communication were prevalent when the project was being done.

In contrast, in Hong Kong, Key stakeholders, which have been identified prior to the workshop, were excluded from the workshop and so the opportunity for these stakeholders to act as a medium for candid and honest communication was lost. In Indonesia, Aapaoja et al. (2013) examined the type of stakeholders that were supposed to be engaged early during the project definition phase. The results were derived from an analysis of literature and empirical studies. Findings showed that projects covered different levels of stakeholders whose requirements and purposes needed to be considered and managed. Early involvement allowed an avenue for innovative answers and a thorough discussion of thoughts. It, therefore, led to events that proceeded in stages, which in turn changed the value of project creation to holistic value co-creation. This study contributes by emphasising on initial involvement of stakeholders and the development of incorporated teams through the identification and consolidation of various objectives, responsibilities, roles, and levels of the stakeholders. However, the researchers failed to determine how stakeholders' consultation influences the implementation of projects, a core dependent variable for this study.

In UER of Ghana, Atiibo (2012) studied problems in the management of stakeholders and their influence on the management of the project in empowerment and advocacy NGOs. The sampling method used was purposive one that assisted in selecting thirty-five respondents, which was composed of five key resources individuals, ten lead project officers, and twenty programme and project managers. The research found out that key stakeholders' roles and interests were significant to the functioning of non-governmental organisations. Nevertheless, management of stakeholders was found to be associated with ad-hoc and casual actions and was not institutionalised mostly.

Attibo deduced that various problems experienced were caused by ad-hoc and casual manners and NGOs non-institutionalisation of stakeholder management. In South Africa, Wachi (2016) assessed stakeholder engagement scope and its effect on the growth and execution of an environmental management plan at the project level. The research design chosen was a case study where one project named 'Berg Water Project' was used. Involvement of stakeholder process is agreed to be critical inclusive since it encompasses a wide variety of stakeholders which permits them to have a chance of raising their misgivings and the results that the participatory process was sufficient. Some remarkable flaws of engagement procedures consist of the inability to identify apparent responsibilities and roles of the environmental observer commission - which is the body that represented the affected and interested factions, not being in a situation of identifying open engagement goals, and failure to note possible transactions if social, economic and environmental expectations of stakeholders.

In Kenya, Chinyavu's (2016) study was to validate how the participation of stakeholders through

16 | This work is licensed under a Creative Commons Attribution 4.0 International License. 
consultation affected donor-funded projects' performance. The research was conducted in Kinango, Kwale County. Project beneficiaries, representatives from the project implementation committee, representatives from the institution implementing the project, and representatives from the two donors formed the target respondents for the study. Chinyavu established that the participation of stakeholders through consultation initiatives and project performances was positively related. Whereas stakeholder involvement in project initiation and identification had a positive association with the performance of projects. However, stakeholders' involvement in planning consultations was negatively correlated with project performance. Obare and Ngugi (2014) investigated stakeholders' consultation influence on KeNHA road projects performance. They utilised a descriptive research approach. The study was mixed, comprising of qualitative and quantitative approaches. A total of 251 respondents who consist of organisation management, prequalified consultants and contractors formed the study target population.

Obare and Ngugi established that: organisation of seminars and conferences, feasibility and awareness in stakeholder engagement had a significant positive effect on KeNHA road projects performance. The study by Obare and Ngugi was at KeNHA while this research was done in Machakos County Government water projects. Moreover, Maina (2016) sought to establish the relationship between stakeholder consultation and project performance. The research was guided by a descriptive survey strategy as it enabled the collection of data to answer research questions. The target population involved the following: Automobile vehicle companies, petroleum refining companies, and environmental management organisations, the Ministry of energy, and NEMA. The study revealed that the involvement of stakeholders in the identification of projects had a significant influence on Automobile Emission control project Performance. The results led to the conclusion that the involvement of stakeholders in project identification influenced the performance of the Automobile emission control project. The review of related literature shows that inadequate studies have been done on the County Government front, therefore creating a gap that the study intended to fill

\section{MATERIALS AND METHODS}

This study was anchored on a correlation research design. The target population for the study consists of water projects being implemented by the County Government of Machakos, Kenya (sinking of boreholes, the building of water pans and dams, and connecting piped water) ongoing in Machakos County thirty-nine (39) county assembly wards. Information from the county water officer showed that 172 water projects were being implemented in Machakos County. From these, 1204 respondents managing the projects formed the target population. Considering the target population is high, a sample of 17 water projects consisting of 120 respondents was selected; 17 out of 172 water projects were selected through a simple random sampling method. The questionnaire was used in collecting data. Considering that quantitative and qualitative information was collected, analysis was performed using descriptive and inferential statistics. Descriptive statistics are analysed in the form of frequencies and percentages. Moreover, Pearson correlation was computed to determine the effect of consultation on the implementation of water projects.

\section{RESULTS}

The first research question for this study sought to determine the effect of stakeholder consultation on the implementation of water projects in Machakos County. For projects to take off well, stakeholders need to be adequately consulted so that they can support commencement and set up the project in that area. Therefore, the respondents were asked to indicate the degree to which consultation to all stakeholders before and during the implementation of water projects. Table 1 shows the findings. 
East African Journal of Business and Economics, Volume 4, Issue 1, 2021

Article DOI: https://doi.org/10.37284/eajbe.4.1.472

Table 1: Extent of Stakeholder Consultation in Implementation of Water Projects

\begin{tabular}{llllllll}
\hline Consultation process & SD & D & UD & A & SA & M & SD \\
\hline $\begin{array}{l}\text { The county involved community } \\
\text { members in discussing water }\end{array}$ & $\begin{array}{l}2 \\
\text { problems and ways of addressing } \\
\text { them before initiation of this project }\end{array}$ & $17(18.5)$ & $\begin{array}{l}2 \\
(2.2)\end{array}$ & $\begin{array}{l}39 \\
(42.4)\end{array}$ & $\begin{array}{l}32 \\
(34.8)\end{array}$ & 3.8913 & 1.1431 \\
\hline $\begin{array}{l}\text { The community identified and } \\
\text { prioritised this water project before its } \\
\text { launch }\end{array}$ & $\begin{array}{l}0 \\
(0.0)\end{array}$ & $17(18.5)$ & $\begin{array}{l}6 \\
(6.5)\end{array}$ & $\begin{array}{l}51 \\
(55.4)\end{array}$ & $\begin{array}{l}18 \\
(19.6)\end{array}$ & 3.7609 & .9763 \\
\hline $\begin{array}{l}\text { The stakeholders through engagement } \\
\text { identified that water was the highest } \\
\text { priority they needed the County } \\
\text { Government to support }\end{array}$ & $18(19.6)$ & $\begin{array}{l}5 \\
(5.4)\end{array}$ & $\begin{array}{l}41 \\
(44.6)\end{array}$ & $\begin{array}{l}(38 \\
(30.4)\end{array}$ & 3.8587 & 1.0647 \\
\hline $\begin{array}{l}\text { The stakeholders' input was } \\
\text { considered during initiation of this } \\
\text { water project }\end{array}$ & $\begin{array}{l}2 \\
(2.2)\end{array}$ & $11(12.0)$ & $\begin{array}{l}12 \\
(13.0)\end{array}$ & $\begin{array}{l}55 \\
(59.8)\end{array}$ & $\begin{array}{l}12 \\
(13.0)\end{array}$ & 3.6957 & .9227 \\
\hline $\begin{array}{l}\text { The project beneficiaries' selection } \\
\text { criteria are clear to all stakeholders }\end{array}$ & $\begin{array}{l}0 \\
(0.0)\end{array}$ & $21(22.8)$ & $\begin{array}{l}4 \\
(4.3)\end{array}$ & $\begin{array}{l}58 \\
(63.0)\end{array}$ & $9(9.8)$ & 3.5978 & .9499 \\
\hline $\begin{array}{l}\text { Stakeholders participated in } \\
\text { feasibility studies }\end{array}$ & $\begin{array}{l}0 \\
(0.0)\end{array}$ & $15(16.3)$ & $\begin{array}{l}6 \\
(6.5)\end{array}$ & $\begin{array}{l}51 \\
(55.4)\end{array}$ & $\begin{array}{l}20 \\
(21.7)\end{array}$ & 3.8261 & .9563 \\
\hline $\begin{array}{l}\text { Average data } \\
(0.7)\end{array}$ & $17(18.0)$ & $\begin{array}{l}6 \\
(6.3)\end{array}$ & $\begin{array}{l}49 \\
(53.4)\end{array}$ & $\begin{array}{l}20 \\
(21.6)\end{array}$ & 3.7718 & 1.0022 \\
\hline
\end{tabular}

Key: SD - Strongly Disagree, D - Disagree, UD - Undecided, A - Agree and SA - Strongly Agree.

Table 1 results showed that $39(42.4 \%)$ of respondents agreed that the county involved residents in discussing water problems issues and ways of addressing them before initiation of the project, $32(34.8 \%)$ strongly agreed, $17(18.5 \%)$ were undecided, while $2(2.2 \%)$ disagreed. The responses show that communities' water problems are discussed and a solution is found on how to address it before initiation of any water project in Machakos County. This ensures that the implementing agency has in mind the specific requirements of the people during the implementation phase. When asked as to whether the community identified and prioritised the water project before it was launched, 17 (18.5\%) disagreed, $6(6.5 \%)$ were undecided, 51 (55.4\%) agreed, and 18 (19.6\%) strongly agreed. This, therefore, shows that there is a prioritisation of water projects before they are launched in Machakos County. Thirdly, 41 (44.6\%) of respondents agreed that stakeholders through engagement identified that they needed water projects. Only $18(19.6 \%)$ disagreed with the statement. The result, therefore, implies that project identification is a consultative process where residents give their input on the type of project they need before the county government implements it.

Most of the respondents $(55,59.8 \%)$ agreed that stakeholders' input was always taken into consideration during the initiation and execution of projects. This implies that stakeholders' contribution is highly valued during the implementation of projects. When asked as to whether project beneficiaries' selection criteria are clear to all stakeholders, 21 (22.8\%) were undecided, $4(4.3 \%)$ were undecided, $58(63.0 \%)$ agreed and $9(9.8 \%)$ strongly agreed. The result, therefore, shows that selection criteria for water projects are clear to all those directly and indirectly affected by it. When asked as to whether all stakeholders participated in feasibility studies, 15 (16.3\%) disagreed, $6(6.5 \%)$ were undecided, 51 $(55.4 \%)$ agreed and $20(21.7 \%)$ strongly agreed. This, therefore, shows that before projects are conceived, a feasibility study is done for all stakeholders. Average data shows that most 49 (53.4\%) of respondents agreed that stakeholders are regularly consulted prior to the implementation of water projects in Machakos county.

18 This work is licensed under a Creative Commons Attribution 4.0 International License. 
Hypothesis testing

Ha: There is a significant effect of stakeholder consultation on water projects implementation by the county government of Machakos, Kenya

\begin{tabular}{lll}
\hline & & Implementation of water project \\
\hline Stakeholder consultation & Pearson Correlation & 0.652 \\
& Sig. (2-tailed) & 0.001 \\
& $\mathrm{~N}$ & 92 \\
\hline
\end{tabular}

Correlation statistics shows that there exists significant positive effect $(\mathrm{r}=0.652, \mathrm{p}=0.001)$ between stakeholder consultation and implementation of water project. The hypothesis is accepted leading to the conclusion that stakeholder consultations key towards water project implementation.

\section{DISCUSSIONS}

Results show that most (72.8\%) of respondents reported that project beneficiary selection criteria were clear to all stakeholders. This meant that all concerned stakeholders were communicated and consulted on the reasons and decisions resulting in the choosing of a particular water project. In line with the study findings, Serhan and Draganov (2016) found out that PMCs focused on implementing sustainable projects were using more communication skills and ere involving more stakeholders in their communication processes. This shows the importance of communication in project implementation. In contrast to the study findings, Teye et al. (2016) warned that the involvement of stakeholders is now a global programme for making a sure complete representation of residents through sharing; decisions, feelings, and ideas relating to projects being developed in their locality. They found out that failure of implementation of projects was not due to poor execution but poor engagement, consultation, and collaboration with stakeholders. Furthermore, it became evident that stakeholders' input was highly valued $(72.8 \%)$ since they were considered during the project initiation stage. This suggests that the law requiring public participation before implementation and commencement of public projects was followed to the latter in the county. This explains why there was a strong positive correlation $(r=0.652)$ between the strategy of consulting stakeholders and water projects implementation in the county. In agreement with this finding, Wanyera's (2016) correlation analysis established that there existed a strong positive correlation between the various characteristics of community involvement and societal-based projects sustainability. Lack of adequate stakeholder consultation may derail the project and sometimes the public may react against it. Therefore, residents of Machakos County were given the platform of identifying and prioritising the kind of water projects they needed the county government to implement in their locality.

\section{CONCLUSIONS AND RECOMMENDATIONS}

It has been established that consultation of stakeholders was conducted on many fronts. At first, the community members' views were wellfactored through consultative meetings to prioritise and plan water projects to be implemented in a particular ward. It was found out that as part of the consultation process, the community members were taken through the project selection criteria before providing approval for the said project to be carried out in their locality. This was also supported by the fact that during feasibility studies, all stakeholders took part while others were given chance to voice their opinion with regard to what they needed the project to be. This, therefore, showed that increased stakeholder consultation meetings resulted in effective water projects implementation in the County of Machakos. The first study's null hypothesis was discarded leading to the conclusion that there existed a significant strong positive effect between stakeholder consultation and water projects implementation in the county of Machakos, Kenya. As part of improving the stakeholder consultation process, the respondents through an open-ended question in the last part of the study tools suggested that there is a need for identification of link persons or officials who will always represent them during the implementation process.

19 | This work is licensed under a Creative Commons Attribution 4.0 International License. 


\section{REFERENCES}

Aapaoja, A., Haapasalo, H., \& Soderstrom, P. (2013). Early stakeholder involvement in the project definition phase: Case renovation. ISRN Industrial Engineering, 14, 1 - 15.

Adan, I. H. (2012). Influence of stakeholders role on performance of constituencies development fund projects a case of Isiolo North Constituency, Kenya (Doctoral dissertation, University of Nairobi, Kenya).

Atiibo, K. A. (2012). Examining stakeholder management challenges and their impact on project management in the case of advocacy and empowerment NGOs in the Upper East Region of Ghana. MBA Thesis, Kwame Nkrumah University of Science and Technology.

Bashir, H. (2010). Stakeholder involvement, project ethical climate, commitment to the project and performance of poverty eradication projects in Uganda: A study of NAADS projects in Mukono District. Masters of Business Administration, Makerere University.

Chinyavu M. R. (2016). The influence of stakeholder participation on the performance of donor funded projects: A Case of Kinango Integrated Food Security and Livelihood Project (KIFSLP), Kwale County, Kenya. MAPPM Project, University of Nairobi.

Fikkert, J. P. B. (2015). Stakeholder engagement and sustainability integration; a case study of royal Ahold (Master's thesis).

International Finance Corporation-IFC (2007). Stakeholder engagement: A good practice handbook for companies doing business in emerging markets. Retrieved online from https://www.ifc.org/wps/wcm/connect/topics_e xt_content/ifc_external_corporate_site/sustaina bility- at- ifc/publications/publications_handboo k_stakeholderengagement_wci_1319577185 063

Kaur, A. (2014). Stakeholder engagement in sustainability accounting and reporting: A study of Australian local councils. University of South Australia.
Maina, E.N. (2016). Influence of stakeholders' involvement on project performance: A case of NEMA automobile emission control project in Nairobi County, Kenya. M.A. Project, University of Nairobi, Kenya.

Malachira, A. R. (2017). Six key components of Collaboration in Higher Education buildings: a case study of Stakeholder Engagement at the University of Washington (Doctoral dissertation).

Mannya, C. (2012). Stakeholder involvement in strategic planning and management at the Ekurhuleni Metropolitan Council (Doctoral dissertation, Stellenbosch: Stellenbosch University).

Mortensen, L. (2016). Stakeholder engagement within strategic environmental management: the case of Port of Aalborg. Master thesis, Aalborg University Denmark.

Ndirangu, J.N. (2021). Stakeholders' participation and performance of Kiserian township sanitation project in Kajiado county, Kenya. Msc. Thesis, Moi University.

Obare, F.N. \& Ngugi, K. (2014). Influence of Stakeholders' Participation on Performance of Road Projects at Kenya National Highways Authority. European Journal of Business Management, 1(11), 1-20.

Pellinen, K. (2016). CSR communication challenges: communication channels, sustainability reporting, and stakeholder engagement. A case study of four Finnish companies (Master's thesis, Nord Universitet).

Project Management Institute-PMI (2013). PMI 2012 annual report. Washington: PMI.

Rowlinson, S. \& Cheung, Y. K. F. (2018). Stakeholder management through empowerment: modelling project success. Economics, 26, 611-623.

Serhan, A., \& Draganov, A. (2016). Project managers' communication skills and stakeholder engagement in sustainable construction projects.

20 This work is licensed under a Creative Commons Attribution 4.0 International License. 
Shah, M., \& Naqvi, I. H. (2014). Impact of internal stakeholder's engagement on project portfolio management success, IT industry in Lahore, Pakistan. Sci. Int. (Lahore), 26(4), 1777-1782.

Teye, J.B., Amofa, D., \& Atsrim, F. (2016). Stakeholder Management on Construction Projects: A Key Indicator for Project Success. American Journal of Civil Engineering, 4(4), 117-126.

Wachi, B. (2016). Assessing the scope and effectiveness of stakeholder engagement in the development and implementation of the Environmental Management Plan for the Berg Water Project in the Western Cape Province, South Africa. M.Phil Dissertation, University of Cape Town South Africa.

Waghmare, Y. M., Bhalerao N. \& Wagh, S.V. (2016). Analysis of the Factors Affecting the Stakeholder Management Process in Building Construction Project. International Journal of Innovative Studies in Sciences and Engineering Technology, 2(7), 48-56.

Wanyera, L. A. (2016). Influence of community participation on sustainability of communitybased projects: a case of Kiambiu water and sanitation slum project, Nairobi County, Kenya (Doctoral dissertation, University of Nairobi).

21 This work is licensed under a Creative Commons Attribution 4.0 International License. 